\title{
Some aspects of the interpretation of mineral balances
}

\author{
By Dorothy L. Duncan, Commonwealth Bureau of Animal Nutrition, \\ Bucksburn, Aberdeen
}

The general principles of the balance trial and the importance of errors of analysis, collection and sampling and biological error are being dealt with by other speakers. These errors are common to all types of balance trial, and the most important respect in which mineral balances differ from those of nitrogen, carbon and energy is in the absence of gaseous products, which means that both collection and analysis are simpler. I shall assume that the trial has been made with all the refinements of technique required, and confine this paper to the examination of the results.

For some 40 years, since Mitchell developed his method for estimating biological value, the balance trial has been shown to give satisfactory practical comparisons of the nutritive values of foods, such as sources of protein or of calcium. Difficulties arise only when the balance trial is used to measure absolute instead of relative values, when we assume that positive balance is identical with accretion of an element in the body, for which the term retention will be used, and negative balance with depletion. Unlike the assumption that analyses are accurate, which can be tested statistically, this one is not easy to test. It has to be examined by considering the changes in the body of the animal represented by the loss or gain of the amounts of material indicated by the balance results. That can be done only if we possess enough information on variations in body composition of the type of animal being studied.

The production of laboratory animals of inbred strains and also in recent years the breeding of very uniform strains of commercial poultry has made available stocks of small animals of high uniformity. With such genetically homogeneous animals it is possible to select at the start of an experiment two groups so well matched that the mean composition of the carcasses of one group represents with measurable probability the mean of the living cohort group also. Comparison of the composition of the first group at the start of the experiment with that of the second group at the end is equivalent, within calculable limits, to measuring the changes which have occurred in the second group. Hence when cohort analyses are combined with balance studies of the same animals they provide an excellent check on the accuracy of the balances. But of course this applies only to uniform populations, and two difficulties arise in the study of large livestock or man. The first is that the accuracy of the carcass analysis begins to decline as a result of the increased difference in magnitude between size of sample and bulk of carcass, leading to magnification of analytical error. The second, and more serious, is that genetically inhomogeneous populations such as ordinary farm animals or men are too variable to provide cohort groups, though variation in some farm animals may be reduced by the use of identical twins. In addition, slaughter experiments are expensive with large animals, which probably explains the paucity of information on the carcass composition of cattle, and are impossible with men. Usually it is necessary to rely on indirect methods of studying 
body composition in the live subject, and many of these methods are as yet insufficiently refined to measure any but gross changes. At present there is not nearly enough information on normal variations in the composition of man or large livestock. If these variations are to be used as a check on balance results, it is essential that the balance trial should run long enough to allow of measurable change in body composition.

I propose to discuss two pairs of minerals, calcium and phosphorus and sodium and potassium, commonly studied by the balance method but requiring differences of approach in the interpretation of the balance results. In both instances the balance trial usually consists in estimation of the minerals in food, if necessary also in drinking water, in urine and faeces and, when appropriate, in milk, eggs, or the products of conception.

\section{$C a$ and $P$}

The important point about these minerals in the body is that they exist mainly in the skeleton; according to Ellenberger, Newlander \& Jones (1950), in adult cows about $98.5 \%$ of the total $\mathrm{Ca}$ and $87 \%$ of the $\mathrm{P}$ are in the bones. And the mineral content of the bones is to a large extent independent of the composition of the rest of the body; on the one hand, the mineral content of the skeleton can vary within quite wide limits without any change in the rest of the body, so that the skeleton is used to regulate the $\mathrm{Ca}$ and $\mathrm{P}$ content of the remaining tissues and, on the other hand, in adult animals at least, changes in weight and composition of the soft tissues can occur with little effect on the skeleton. Excretion of those minerals results from a combination of intake and events in the skeleton; for instance, the negative $\mathrm{Ca}$ balance in a cow at the start of lactation does not necessarily reflect an insufficient $\mathrm{Ca}$ intake but rather the endocrine condition which brings about the mobilization of skeletal $\mathrm{Ca}$. It is therefore impossible to use changes in weight as a test for the accuracy of $\mathrm{Ca}$ and $\mathrm{P}$ balances, and as a result the interpretation of the balances is exceptionally difficult. Changes in the labile pools are measurable with radioactive nuclides, but as we have seen the labile pools are a small proportion of the total minerals and measurement of changes in the reserves more or less firmly fixed in bone is much more tedious.

Without repeating here the surveys of balance trials in small and large animals made elsewhere (Duncan, I958, I966), one may summarize the conclusions. In rats it appears to be possible to conduct $\mathrm{Ca}$ balance trials which are a satisfactory indication of changes in the body and which are without cumulative bias. This is probably true also of $\mathrm{P}$; there may be a systematic error but it is a small one. Freese (I958) obtained good agreement between balance results and carcass analyses with baby pigs up to 35 days of age. Such agreement has not, so far as I can find, been demonstrated with other animals. Cohort analyses with balance studies were made on hens by Jenkins \& Tyler (1960) and also by Hurwitz \& Griminger (1960, 1962), but in all instances excessive positive balances of $\mathrm{Ca}$ were obtained. In dairy cows the Vermont studies of Ellenberger and his colleagues (Ellenberger et al. 193 1, 1932, 1936, 1950; Newlander, Ellenberger \& Jones, 1936) gave large cumulative positive balances of 
both $\mathrm{Ca}$ and $\mathrm{P}$ which could not be confirmed by the carcass analyses. It is usual to ascribe these unexplained positive balances to dermal and salivary losses by cattle; in Vermont an attempt was made to recover such material by brushing the cattle and by washing the mattresses on which they lay, but the amounts of $\mathrm{Ca}$ and $\mathrm{P}$ so recovered did not prevent cumulative error. There is no information about the extent of such losses to be expected in livestock.

In man we cannot use analyses to confirm balance results, and some attempts have been made to take account of dermal losses, notably by Consolazio and others at the US Army Medical Research Nutrition Laboratory (Consolazio, Matoush, Nelson, Hackler \& Preston, I962; Consolazio, Matoush, Nelson, Harding \& Canham, 1963; Consolazio, Matoush, Nelson, Isaac \& Canham, I966), who concluded that it is essential to consider Ca losses in sweat but that dermal loss of $\mathrm{P}$ did not form an important proportion of total output. Unfortunately their work has also shown how variable the dermal losses are, so that no standard correction for them can be applied. Leitch \& Aitken (1959) have concluded that the uncertainties are such as to make the balance trial an unsuitable tool for the estimation of Ca requirement in man; as a tool for the study of Ca metabolism it has been superseded except in conjunction with isotope studies.

\section{$\mathrm{Na}$ and $K$}

Here we are faced with quite other problems. Although the skeleton has a considerable $\mathrm{Na}$ content it contains very little $\mathrm{K}$ and there is no specific store of these elements in the tissues: homoeostatic control is achieved, not by isolation of any excess in a reserve, but through renal excretion. In that characteristic, $\mathrm{Na}$ and $\mathrm{K}$ are more akin to nitrogen than to $\mathrm{Ca}$. The most important function of the homoeostatic mechanism for these electrolytes is the maintenance of ionic equilibrium, which accounts for the fact that although the $\mathrm{Na}$ and $\mathrm{K}$ contents of tissues are rather variable individually the sum of both tends to remain constant. For example, Blaxter \& Rook (1957a,b) showed that in cattle the coefficient of variation of the $\mathrm{Na}$ concentration in tissue water of muscle was $\pm 28.4 \%$ and that of $\mathrm{K}$ was of the same order, but for the sum of both the variation was only $4.4 \%$ and similar to that in blood and plasma. In fact, the $\mathrm{Na}$ plus $\mathrm{K}$ content in normal cattle was sufficiently constant for Blaxter \& Rook to conclude that balances of those elements could be used to estimate retention of water without significant systematic error. The Agricultural Research Council: Working Party on Nutrient Requirements of Ruminants (I965) obtained from carcass analyses of steers by Hogan \& Nierman (1927) regression equations relating the $\mathrm{Na}$ and $\mathrm{K}$ contents of cattle to their body-weight, and such equations may serve to indicate in a somewhat crude way whether balance values in cattle are of the magnitude to be expected in a normal animal.

Unfortunately this does not mean that there is no difficulty in the interpretation of balance results in large animals. When Blaxter \& Rook (1957a,b) attempted to relate $\mathrm{Na}$ and $\mathrm{K}$ balances to body composition in sheep they found that balances of $\mathrm{K}$ were excessively positive when interpreted as changes in tissue concentrations, and that the discrepancy resulted from the large losses of $K$ through the skin of 
sheep. They could not find measurable dermal losses of either mineral in cattle. On the other hand, Kemp (1964) in short-term balance trials with cows obtained apparent retentions of 2.5-5 $\mathrm{g} \mathrm{Na}$ daily in cows on adequate $\mathrm{Na}$ intake; as such retentions appeared improbable in an adult animal, Kemp assumed that $2.5 \mathrm{~g}$ would represent dermal and salivary losses near the maintenance level and used that figure when calculating $\mathrm{Na}$ requirement. But it seems likely that such losses would be variable. If we apply Kemp's method of calculation to a cow given an adequate amount of $\mathrm{Na}$ in a recent long-term study of $\mathrm{Na}$ metabolism by Helfferich, Bauer $\&$ Lenkeit ( 1965 ), we get a figure of about $0.75 \mathrm{~g}$ daily for otherwise unexplained losses. Those workers made no allowance for such loss in calculating cumulated losses by a cow given insufficient $\mathrm{Na}$.

As with $\mathrm{Ca}$, the loss of electrolytes through the human skin has been the subject of study. Consolazio and his colleagues (Consolazio, Nelson et al. I963) showed that, in young men exposed to heat, dermal losses accounted for from 54 to $68 \%$ of total daily output of $\mathrm{Na}$ and from $\mathrm{r} 9$ to $44 \%$ of that of $\mathrm{K}$, and that correction for the losses of $\mathrm{K}$ in each instance turned an apparently positive into a negative balance.

In ruminants there is yet another complication, especially important in short-term balance studies. Kemp \& Geurink ( 1966 ) have calculated that, as a result of the rapid responses by the salivary glands to changes in supplies of $\mathrm{Na}$ and $\mathrm{K}$, leading to large changes in the amounts of those electrolytes secreted into the digestive tract, the rumen in cattle may be considered as a readily accessible reserve from which up to 200 $\mathrm{g} \mathrm{Na}$ may be withdrawn in time of shortage. In sheep, acute depletion caused the $\mathrm{Na}$ content of saliva to fall from $172 \cdot 6$ to $38 \cdot 2$ m-equiv./l. (Phillips \& Sundaram, 1966). Dobson, Scott \& Bruce (1966) have shown recently that in sheep large changes in $\mathrm{Na}$ and water and somewhat smaller changes in $\mathrm{K}$ content in the rumen may result from a change in the type of diet, and not necessarily as a result of changes in the amounts of the minerals themselves in the diet but, for example, after a change from grass to hay and meals. As a result of the change in the rumen reserve, the immediate changes in balance resulting from a change of diet were not always appropriate to the change in intake of minerals or an indication of changes in body composition.

My conclusion is that in our present state of knowledge the balance trial is of dubious value in studies of $\mathrm{Na}$ and $\mathrm{K}$ retention. Almost certainly, with large livestock as with man, it will prove easier to measure changes in body composition directly. This can be done with radioactive nuclides; Wilson, Olney, Brooks, Myrden, Ball \& Moore (I954) compared such measurements with the results of balance studies on human patients and concluded that "the errors and limitations of the isotope measurements are more readily ascertained, and are not cumulative. The errors are random and are not magnified by the passage of long time intervals.' Apfelbaum \& Trémolières (1965) showed that exchangeable $\mathrm{K}$, which represents a large proportion of total body $\mathrm{K}$, is closely related to active tissue mass and is readily measured with ${ }^{42} \mathrm{~K}$. $\mathrm{K}$ has in addition the advantage over $\mathrm{Na}$ that it can be measured even more readily in the whole-body $\gamma$-spectrometer. That was done by Kaul, Jekat \& Starlinger $(1965)$ in young men and, although the agreement between changes in body 
$\mathrm{K}$ measured directly and by balance trials was within I0\%, the time seems to have come to ask ourselves seriously whether the mineral balance trial has not had its day.

\title{
REFERENCES
}

Agricultural Research Council: Working Party on Nutrient Requirements of Ruminants (1965). The Nutrient Requirements of Farm Livestock. No. 2. Ruminants. London: HM Stationery Office.

Apfelbaum, M. \& Trémolières, J. (r965). Nutritio Dieta 7, 24r.

Blaxter, K. L. \& Rook, J. A. F. (1957a). F. agric. Sci, Camb. 48, 194.

Blaxter, K. L. \& Rook, J. A. F. (1957b). F. agric. Sci., Camb. 48, 2 10.

Consolazio, C. F., Matoush, LeR. O., Nelson, R. A., Hackler, L. R. \& Preston, E. E. (1962). F. Nutr. 78,78 .

Consolazio, C. F., Matoush, LeR. O., Nelson, R. A., Harding, R. S. \& Canham, J. E. (r963). F. Nutr. 79, 407.

Consolazio, C. F., Matoush, LeR. O., Nelson, R. A., Isaac, G. J. \& Canham, J. E. (I966). Am. F. clin. Nutr. 18, 443 .

Consolazio, C. F., Nelson, R. A., Matoush, LeR. O., Harding, R. S. \& Canham, J. E. (1963). F. Nutr. 79, 399.

Dobson, A., Scott, D. \& Bruce, J. B. (1966). Q. Fl exp. Physiol. 51, 31 I.

Duncan, D. L. (1958). Nutr. Abstr. Rev. 28, 695.

Duncan, D. L. (1966). In Recent Advances in Animal Nutrition. [J. T. Abrams, editor.] London: Churchill.

Ellenberger, H. B., Newlander, J. A. \& Jones, C. H. (1931). Bull. Vt agric. Exp. Stn no. 331.

Ellenberger, H. B., Newlander, J. A. \& Jones, C. H. (1932). Bull. Vt agric. Exp. Stn no. 342.

Ellenberger, H. B., Newlander, J. A. \& Jones, C. H. (1936). F. Dairy Sci. 19, 444.

Ellenberger, H. B., Newlander, J. A. \& Jones, C. H. (1950). Bull. Vt agric. Exp. Stn no. 558.

Freese, H. H. (1958). Arch. Tierernähr. 8, 330.

Helfferich, B., Bauer, R. \& Lenkeit, W. (I965). Z. Tierphysiol. Tierernähr. Futtermittelk. $20,95$.

Hogan, A. G. \& Nierman, J. L. (1927). Res. Bull. Mo. agric. Exp. Stn no. Io7.

Hurwitz, S. \& Griminger, P. (1960). F. agric. Sci., Camb. 54, 373.

Hurwitz, S. \& Griminger, P. (r962). F. Sci. Fd Agric. 13, 185.

Jenkins, N. K. \& Tyler, C. (1960). F. agric. Sci., Camb. 54, I 3 I.

Kaul, A., Jekat, F. \& Starlinger, H. (1965). Int, Z, angew. Physiol. 21, 62.

Kemp, A. (1964). Neth. F. agric. Sci. 12, 263.

Kemp, A. \& Geurink, J. H. (1966). Tijdschr. Diergeneesk. 9r, 580.

Leitch, I. \& Aitken, F. C. (r959). Nutr. Abstr. Rev. 29, 393.

Newlander, J. A., Ellenberger, H. B. \& Jones, C. H. (1936). Bull. Vt agric. Exp. Stn no. 406.

Phillips, G. D. \& Sundaram, S. K. (I966). F. Physiol., Lond. 184, 889.

Wilson, G. M., Olney, J. M., Brooks, L., Myrden, J. A., Ball, M. R. \& Moore, F. D. (1954). Metabolism 3, 324.

\section{A critical evaluation of the mineral and nitrogen balances in man}

\author{
By B. Isaksson and B. Sjögren, Metabolic Ward, Sahlgren's Hospital \\ and University of Göteborg, Göteborg, Sweden
}

The prevalence of certain important errors inherent in the metabolic balance technique (Reifenstein, Albright \& Wells, r945) is well known to workers in the field. Nevertheless, ignorance of this knowledge is not uncommon when interpreting the data (Walker, 1962; Mitchell \& Edman, 1962). As will be shown below, the orthodox definition of the balance as the difference between intake of an element and its excretion with urine and faeces is incomplete. Regardless of this fact, the technique requires as accurate intake and excretion figures as possible, since these figures are usually high compared with the balance. Even a slight error in the intake 